\title{
A Streptococcus pneumoniae (pneumococcus) -infekciók ezer arca
}

\author{
Szabó Bálint Gergely dr. ${ }^{1,3,4}$. Lénárt Katalin Szidónia dr. ${ }^{1,3}$ \\ Kádár Béla dr. ${ }^{1,3,4}$ - Gombos Andrea dr. ${ }^{1,3}$ - Dezsényi Balázs dr. ${ }^{1}$ \\ Szanka Judit dr. ${ }^{1}$ - Bobek Ilona dr. ${ }^{4}$ - Prinz Gyula dr. ${ }^{1,3}$ \\ Egyesített Szent István és Szent László Kórház-Rendelőintézet, ${ }^{1}$ I. Infektológiai Osztály, \\ ${ }^{2}$ Központi Anaesthesiologiai és Intenzív Betegellátó Osztály, Budapest \\ ${ }^{3}$ Semmelweis Egyetem, Általános Orvostudományi Kar, II. Belgyógyászati Klinika, \\ Infektológiai Tanszéki Csoport, Budapest \\ ${ }^{4}$ Semmelweis Egyetem, Doktori Iskola, Budapest
}

\begin{abstract}
A Streptococcus pneumoniae (pneumococcus) által okozott infekciók világszerte, így Magyarországon is, tartósan magas morbiditási és mortalitási mutatókkal rendelkeznek a gyermek- és felnőttpopulációban egyaránt. A felnőttkori, hospitalizációt igénylő, otthon szerzett tüdőgyulladások 35-40\%-ában a pneumococcus kóroki szerepe igazolható, az S. pneumoniae-pneumoniák 25-30\%-a bacteraemiával jár. Az összes fertőzés 5-7\%-a fatális kimenetelü, idősek és rizikóbetegek körében az arány meredeken növekedik. A súlyos, invazív formában zajló infekciók esetében a mortalitás elérheti a $20 \%$-ot, a szövődményráta adekvát antibiotikus terápia mellett is jelentős. A szerzők összefoglalják a pneumococcalis betegségek epidemiológiáját, a noninvazív és invazív fertőzések patogenezisét, valamint prezentálják a legfontosabb klinikai aspektusokat esetbemutatásokon keresztül. A betegek rizikóstratifikációja, a hemokultúrák vétele és a korai antibiotikum-kezelés mellett az aktív immunizáció széles körü alkalmazása segíthet csökkenteni az invazív fertőzések mortalitását. A pneumococcus elleni vakcináció javasolt minden 50 év feletti felnőttnek, illetve minden 18 év feletti krónikus betegnek, aki alapbetegsége miatt fogékony a pneumococcalis infekcióra. Orv. Hetil., $2015,156(44), 1769-1777$.
\end{abstract}

Kulcsszavak: pneumococcus, Streptococcus pneumoniae, invazív pneumococcusbetegség, IPD, konjugált vakcina, poliszacharidvakcina

\section{Thousand faces of Streptococcus pneumoniae (pneumococcus) infections}

Incidence and mortality rates of infections caused by Streptococcus pneumoniae (pneumococcus) are high worldwide and in Hungary among paediatric as well as adult populations. Pneumococci account for 35-40\% of community acquired adult pneumonias requiring hospitalization, while $25-30 \%$ of Streptococcus pneumoniae pneumonias are accompanied by bacteraemia. $5-7 \%$ of all infections are fatal but this rate is exponentially higher in high risk patients and elderly people. Mortality could reach $20 \%$ among patients with severe invasive pneumococcal infections. Complications may develop despite administration of adequate antibiotics. The authors summarize the epidemiology of pneumococcal infections, pathogenesis of non-invasive and invasive disease and present basic clinical aspects through demonstration of four cases. Early risk stratification, sampling of hemocultures, administration of antibiotics and wider application of active immunization could reduce the mortality of invasive disease. Anti-pneumococcal vaccination is advisable for adults of $\geq 50$ years and high risk patients of $\geq 18$ years who are susceptible to pneumococcal disease.

Keywords: pneumococcus, Streptococcus pneumoniae, invasive pneumococcal disease, conjugated vaccine, polysaccharide vaccine

Szabó, B. G., Lénárt, K. Sz., Kádár, B., Gombos, A., Dezsényi, B., Szanka, J., Bobek, I., Prinz, Gy. [Thousand faces of Streptococcus pneumoniae (pneumococcus) infections]. Orv. Hetil., 2015, 156(44), 1769-1777.

(Beérkezett: 2015. szeptember 9.; elfogadva: 2015. szeptember 30.) 


\section{Rövidítések}

$\mathrm{ABRS}=$ akut bakteriális rhinosinusitis; $\mathrm{AOM}=$ akut otitis media; $\mathrm{CAP}=($ communitiy acquired pneumonia $)$ közösségben szerzett pneumonia; $\mathrm{CDC}=($ Centers for Disease Control and Prevention) Infekciókontroll és Prevenciós Központ; COPD = (chronic obstructive pulmonary disease) krónikus obstruktív tüdőbetegség; CRP = C-reaktív protein; IPD =(invasive pneumococcal disease) invazív pneumococcusbetegség; iv. = intravénás; $\mathrm{LMWH}=$ (low molecular weight heparin $)$ alacsony molekulasúlyú heparin; $\mathrm{O}_{2} \mathrm{Sat}=\mathrm{O}_{2}$-szaturáció; OEK = Országos Epidemiológiai Központ; $\mathrm{p}_{\mathrm{a}} \mathrm{CO}_{2}=$ artériás parciális $\mathrm{CO}_{2}$-tenzió; $\mathrm{p}_{\mathrm{a}} \mathrm{O}_{2}=$ artériás parciális $\mathrm{O}_{2}$-tenzió; $\mathrm{PCT}=$ prokalcitonin; p. o. = szájon át $($ per os $) ;$ PSI $/$ PORT score $=($ Pneumonia Severity Index/Pneumonia Outcomes Research Team) pneumoniasúlyossági index; $\mathrm{RTG}=$ röntgen; $\mathrm{sHCO}_{3}{ }^{-}=$standard bikarbonátkoncentráció; $\mathrm{TMP} / \mathrm{SMX}=$ trimetoprim/sulfametoxazol; VVT = vörösvértest

\section{A pneumococcusfertőzések epidemiológiája}

A Streptococcus pneumoniae (pneumococcus) okozta fertőzés világszerte hatalmas terhet ró az egészségügyi szolgáltatókra. A World Health Organization (WHO) felmérése alapján 2000-ben a világon 14,5 millió igazolt pneumococcusfertőzés történt, ezek közül 826000 eset fatális kimenetelúnek bizonyult az 1-59 hónapos gyermekpopulációban [1]. A Centers for Disease Control and Prevention (CDC) adatai szerint a felnőttkori pneumococcusinfekciók döntő hányada pneumonia formájában zajlik. Az Amerikai Egyesült Államokban a közösségben szerzett tüdőgyulladások (CAP) 35-40\%-át S. pneumoniae okozza, ez évente közel 900000 ember megbetegedését jelenti [2]. A pneumococcuspneumonia vezet legmagasabb arányban hospitalizációhoz minden korcsoportban: a becslések szerint az Amerikai Egyesült Államok területén éves szinten 400000 beteg kerül kórházi felvételre [3]. Az összes felnőtteset 5-7\%-a fatális kimenetelű, rizikótényezővel rendelkező betegek és idősek körében az arány lényegesen magasabb [4].

Az invazív pneumococcusbetegség (IPD) prevalenciájához hozzájárul, hogy az $S$. pneumoniae okozta tüdőgyulladások 25-30\%-a bacteraemiával jár. Az Amerikai Egyesült Államok területén közel 12000 bacteraemia igazolódik évente, ebben a betegcsoportban a mortalitás elérheti a $20 \%$-ot adekvát antibiotikus kezelés mellett is [4]. Gyermekkorban a felderíthető fókusz nélküli, úgynevezett primer pneumococcusbacteraemia fordul elő leggyakrabban invazív fertőzésként. Egy 2002-2004 között zajló felmérés szerint Magyarországon az 5 évnél fiatalabb gyermekek körében az IPD becsült éves incidenciája 14,9 fó 100000 kiskorúra számítva [5]. A CDC retrospektív vizsgálata alapján az elmúlt évtizedben átlagosan 3000-6000 pneumococcusmeningitist diagnosztizáltak évente, az esetek 15\%-a gyermekpopulációban lépett fel. Az Amerikai Egyesült Államokban S. pneumoniae okozza a bakteriális agyhártyagyulladások 50\%-át, bár ez az arány inkább a Haemophilus influenzae elleni vakcináció bevezetése utáni relatív eltolódást tükrözi. 2012-ben az igazolt pneumococcusbacteraemiák és -meningitisek összesen 3300 halálos áldozatot követeltek, az agyhártyagyulladás önmagában $10 \%$ körüli mortalitással járt [6]. Az Országos Epidemiológiai Központ (OEK) 2004. és 2011. évi adatai alapján hazánkban átlagosan évi 50-60 fó betegedett meg pneumococcusmeningitisben, a mortalitás 30\% körül mozgott, míg egy budapesti kórház statisztikáját figyelembe véve az 1998 és 2007 között pneumococcusmeningitis miatt kezelt $1-18$ éves gyerekek halálozási aránya $24 \%$ volt $[7,8]$. Magyarországon az IPD valós incidenciájának korrekt felmérését nehezíti, hogy nagy esetszámú multicentrikus epidemiológiai vizsgálatok szinte alig készültek, európai tanulmányokban pedig csak kevés magyar hivatkozás található [9].

\section{A pneumococcus mikrobiológiája}

\section{Pneumococcus pneumonia kockázati tényezöpel rendelkez" fiatal betegben}

„A 33 éves nőbeteg anamnézisében csontfájdalom kapcsán egy hónapja diagnosztizált myeloma multiplex szerepelt. A felvételt megelőző héten influenzára típusos panaszai (hirtelen kezdetû magas láz, ízületi és izomfájdalom, fejfájás, kifejezett gyengeség) jelentkeztek, azonban a lázak nem csillapodtak, majd 4 nap múlva jelentős produktív köhögés és addig nem tapasztalt hidegrázások indultak. Vizsgálata során panaszai súlyosságához képest kielégítő általános állapotot találtunk, az egyetlen fizikális eltérés a bal oldali tüdőbázis feletti crepitatio volt. Laborjában anaemiát $(100 \mathrm{~g} / \mathrm{l} \mathrm{Hgb})$, thrombopeniát (36 G/1) és emelkedettebb CRP-t $(62 \mathrm{mg} / \mathrm{l})$ találtunk. A beteg mellkasfelvételén bal felső lebenyi típusos lobaris infiltrátum ábrázolódott, a PSI/PORT score 52/II volt. A felvételi hemokultúrák 2 nap múlva jeleztek, belőlük 33F szerotípusú Streptococcus pneumoniae volt izolálható. A beteg 5 napig iv. $1 \times 2$ g ceftriaxonterápiában részesült, emellett lázai és légúti panaszai teljesen megszúntek, gyulladásos laboreltérései normalizálódtak. A 6. napon készült kontroll-röntgenfelvételen a homály lényeges regressziót mutatott, a beteget így további 4 napra rendelt p. o. $3 \times 1000 \mathrm{mg}$ amoxicillinnel otthonába emittáltuk."

$\mathrm{Az}$ S. pneumoniae Gram-pozitív fakultatív anaerob diplococcus, amely kolonizálhatja az egészséges emberek nasopharynxát. A tünetmentes hordozás felnőttekben 40-50\%, gyerekekben magasabb, 50-70\% körüli [10]. A felnőttkori hordozás átlagosan 4-6 hétig perzisztál, dohányosoknál gyakoribb és több szerotípust is involválhat egyazon gazdaszervezetben. Vizsgálatok szerint az új szerotípusok a kisgyermekek közvetítésével kerülnek a családba, valamint feltehetően ők szolgálnak rezervoárként a magasabb antibiotikum-rezisztenciát mutató variánsok számára $[11,12]$. Az antibiotikum-éra kezdetén a baktérium teljes penicillinérzékenységet mutatott, az 
1970-es évekre azonban Dél-Afrikában megjelentek az első rezisztens törzsek. A rezisztencia nagyfokú geográfiai eltéréseket mutat, a legmagasabb rátát Délkelet-Ázsiában regisztrálták [13]. Az elérhető surveillance-adatok alapján azonban jelenleg a nem idegrendszeri lokalizációjú, felnőttkori IPD-t okozó pneumococcusok nagy valószínûséggel penicillinérzékenyek [14]. Az Amerikai Egyesült Államokban izolált pneumococcustörzsek 96\%-a érzékeny, 3\%-a mérsékelten érzékeny, míg 1\%-a rezisztens ceftriaxonra [6]. Az S. pneumoniae béta-laktám-rezisztenciája nagymértékben dózisdependens, ezért in vivo át lehet törni a választott antibiotikum napi adagjának emelésével. A meningitises esetek kivételével a pneumococcusinfekciók körülbelül 95\%-ában jó klinikai válaszkészséget látunk béta-laktámok adására. A bétalaktámok relatíve alacsony idegrendszeri penetrációja és elérhető liquor-végkoncentrációja miatt a meningealis fertőzéseket okozó törzsek mintegy $80 \%$-a mutat teljes in vivo érzékenységet. A makrolidrezisztencia szintje napjainkra az összes izolátum között eléri a 30\%-ot, monoterápiás használatuk háttérbe szorult. A surveillancetanulmányok további eredményei szerint a légúti fluorokinolonokkal (levofloxacin, moxifloxacin) szemben az $S$. pneumoniae törzsek kevesebb mint 1\%-a mutat rezisztenciát, ciprofloxacinra nézve ez az arány $2 \%$ körül jár [15], bár bizonyos országokban (például Hongkong) a kinolonrezisztencia magasabb prevalenciájú [16]. A tetracyclinrezisztencia világszerte $6-40 \%$ között mozog, az átlagos ráta $20 \%$ körülire tehető [17]. A trimetoprim/ sulfametoxazol (TMP/SMX) rezisztencia akár 25-80\%os is lehet, a várható rezisztenciarátában jelentős földrajzi szórás figyelhető meg, ezért ma már nem preferált szer a pneumococcusinfekciók gyógyításában [18]. Az S. pneumoniae vancomycinérzékenysége változatlanul magas fokú [19]. Az OEK surveillance-rendszerében 2013-ban jelentett adatok alapján Magyarországon a makrolid- és TMP/SMX rezisztencia 23-28\% körül mozog, míg a ceftriaxon- és légúti fluorokinolonokkal szembeni rezisztencia $1 \%$ alatti $[20]$.

\section{A pneumococcusfertőzések patogenezise}

\section{Tipusos pneumococcus CAP atipusos panaszokkal}

„A 78 éves férfi beteg anamnézisében évek óta gondozott hypertonia, 2-es típusú cukorbetegség, COPD, dohányzás szerepelt. 1 hete otthonában kezdődő láz, hasmenés és bőrkiütések miatt utalták kórházba. Vizsgálata során a bőrén testszerte számos 1-3 cm-es, konfluáló, erythemás maculát, kifejezett tachydyspnoét, jobb tüdőfél feletti crepitatiót és irreguláris pulzust találtunk. A beteg EKG-ján új keletü, magas kamrafrekvenciájú pitvarfibrilláció, artériás vérgázanalízisén légzési acidosis ( $\mathrm{pH} 7,30, \mathrm{p}_{\mathrm{a}} \mathrm{CO}_{2} 48 \mathrm{Hgmm}, \mathrm{sHCO}_{3^{-}}$16,2 mmol/l) és hypoxaemia $\left(\mathrm{p}_{\mathrm{a}} \mathrm{O}_{2} 53 \mathrm{Hgmm}, \mathrm{O}_{2}\right.$ Sat körlevegőn 86\%) volt. Laboreredményei közül leukocytosis (12,9 G/1,
96,6\% neutrophil), igen magas CRP (285 mg/1), PCT $(3,4 \mathrm{ng} / \mathrm{ml})$ és laktátszint $(6,5 \mathrm{mmol} / \mathrm{l})$ emelhető ki. Mellkasi röntgenjén a jobb tüdőbázis felett homogén infiltrátum és konkomittáló pleuralis folyadék ábrázolódott. A széklettenyésztés és Clostridium difficile toxinkimutatás negatív lett. A klinikai kép bakteriális pneumoniának megfelelt, a beteg PSI/PORT értékét 131/V-nek számítottuk. Az exanthemák miatt felmerült Mycoplasma pneumoniae etiológiai szerepe, ezért empirikusan p. o. $2 \times 500 \mathrm{mg}$ levofloxacint, valamint terápiás dózisú LMWH-t, béta-blokkolót, $\mathrm{O}_{2}$-szupportációt indítottunk. A felvétel napján levett hemokultúrákból 6A szerotípusú, Streptococcus pneumoniae-t izoláltak, ezért a levofloxacint 2 nap után iv. $1 \times 2$ g ceftriaxonra cseréltük, amelyet további 6 napig adtunk. A beteg lázai 48 óra után megszüntek, bőrlaesiói gyors ütemben regrediáltak, laboreltérések normalizálódtak. Nehézlégzése a 4. napra oldódott, székelési habitusa rendeződött. A 6. napon végzett kontrollröntgen a leírt infiltrátum jelentős csökkenését mutatta. I hét után készült EKG-n sinusrhythmus volt, az antikoaguláns adását felfüggesztettük. A beteget szövődmény kialakulása nélkül a 8 . napon emittáltuk."

A pneumococcus humán patogenitása számos virulenciafaktor expressziójára vezethető vissza: 1. a baktérium epithelspecifikus kapcsolódását elősegítő adhezinek; 2. a szöveti penetrációt facilitáló invazinok (például pneumolizin, IgA $\mathrm{A}_{1}$-proteáz, hialuronidáz, neuraminidáz); 3. az antifagociter és antiopszonizációs hatású poliszacharidtok [21]. A tok antigenitása alapján eddig 92 szerotípust izoláltak, adott szerotípussal történő fertőzés átvészelése típusspecifikus immunitást hagy hátra. A szeroprevalenciát nagyban módosítják az életkori, vakcinációs és geográfiai különbségek. Becslések szerint a világon leggyakoribb 10 szerotípus $(1,3,4,5,6,9,14,18,19,23)$ felel az IPD-k 62\%-áért [2]. Úgy tûnik, az IPD rizikója szoros korrelációt mutat a szerotípussal [22, 23, 24]. Egy metaanalízis szerint bizonyos szerotípusokat (például 1 , 5, 7) 60-szor nagyobb valószínüséggel izoláltak invazív fertőzésekből, mint más szerotípusokat (például 3, 6A, 15), utóbbiak viszont aszimptomatikus carrierek mintáiból nőttek gyakrabban. A leggyakoribb invazív szerotípusok így jellemzően a legritkábban izolálhatók tünetmentes hordozók garatváladékából [22]. A szerotípus a meningitisek súlyosságának determinánsa is: egy kutatás bizonyította, hogy például az l-es szerotípus okozta agyhártyagyulladás kisebb mortalitással járt, mint a 3-as szerotípusé [23].

Az S. pneumoniae emberról emberre direkt kontaktus során cseppfertőzéssel (köhögés, tüsszentés) terjed. Fertőzés általában új, a gazdaszervezetet addig nem kolonizáló szerotípus akvirálása után 1-3 nappal alakul ki. A pneumococcus közvetlen terjedésével akut bakteriális rhinosinusitis (ABRS) és otitis media acuta (AOM) alakul ki, míg pneumoniához a pharyngealis flóra aspirációja vezet. Az autoinokulációt elősegíti az eszméletlenség, 
a köhögési és garatreflex renyhesége, valamint a ciliaris dyskinesisek. Előbbi betegségektől eltér az IPD, amely során $S$. pneumoniae jelenléte igazolható steril testnedvet tartalmazó helyről (például vér, liquor, pleuralis fluidum). IPD-ben a pneumococcus nyálkahártya-penetrációja és véráram-inváziója miatt bacteraemia, majd távoli szervek szórása alakul ki. A folyamat eredménye meningitis, szepszis, ritkábban peri- vagy endocarditis, osteomyelitis, arthritis, peritonitis, cellulitis vagy cerebralis abscessus - az irodalom alapján leggyakrabban meningitis és bacteraemia lép fel, a többi prezentáció klinikai prevalenciája az antibiotikumok elterjedése óta visszaszorult. A felnőttkori IPD-k döntő hányadát pneumonia okozza [25]. A pneumococcalis betegségek invazivitás szempontjából átmehetnek egymásba, illetve szimultán is jelentkezhetnek.

\section{A pneumococcusfertőzések kockázati tényezői, szövődményei}

\section{Szövődménnyel gyógyuló pneumococcuspneumonia}

„A 46 éves nőbeteg anamnézisében évtizedek óta gondozott hypertonia, 2-es típusú cukorbetegség, COPD, dohányzás és súlyos alkoholabúzus szerepelt. Otthonában kezdődő 2 hetes hasmenés miatt utalták kórházba. Részletes kikérdezésekor derült fény 5 napja fennálló kínzó, vérköpéssel járó köhögésére. Vizsgálat során tachydyspnoét, bal tüdőfél feletti gyengült légzést és crepitatiót, tachycardiát találtunk. Artériás vérgázanalízisen a tachypnoénak megfeleltethető légzési alkalosis ( $\left.\mathrm{pH} 7,54, \mathrm{p}_{\mathrm{a}} \mathrm{CO}_{2} 29 \mathrm{Hgmm}, \mathrm{sHCO}_{3^{-}} 27,2 \mathrm{mmol} / \mathrm{l}\right)$ és hypoxaemia $\left(\mathrm{p}_{\mathrm{a}} \mathrm{O}_{2} 49 \mathrm{Hgmm}, \mathrm{O}_{2}\right.$ Sat körlevegőn 87\%) volt. Laborleletei közül kiemelendő a leukocytosis $(17,3$ $\mathrm{G} / 1, \quad 85,1 \%$ neutrophil), anaemia (92 g/l Hgb), thrombopenia (46 G/l), azotaemia (19,2 mmol/1 karbamid, $175 \mu \mathrm{mol} / 1$ kreatinin), hyponatraemia (117 $\mathrm{mmol} / \mathrm{l})$ és hypokalaemia $(2,8 \mathrm{mmol} / \mathrm{l})$, magas CRP (368 $\mathrm{mg} / \mathrm{l})$, PCT $(18,0 \mathrm{ng} / \mathrm{ml})$ és laktátszint $(7,9$ $\mathrm{mmol} / \mathrm{l})$. A beteg mellkasfelvételén bal felső lebenyi atelectasia ábrázolódott. Az összeesett tüdőterületen gyulladásos komponenst és következményes szepszist feltételezve hemokultúrákat vettünk, majd empirikusan iv. $1 \times 2$ g ceftriaxont indítottunk. A PSI/PORT értéket 121/ IV-nek számítottuk. A hypoxiát $\mathrm{O}_{2}$-pótlással, az ion- és vesefunkciós eltéréseket parenteralis krisztalloid infundálásával ellensúlyoztuk, a vérszegénység 4 egység vvt.koncentrátum transzfúzióját igényelte. A beteg fürészelő lázmenete és gyulladásos laboreltérései 5 napos antibiotikum-kúra után is perzisztáltak. Kontroll mellkasi RTGen regresszió nem látszódott, viszont az érintett oldalon pleuralis fluidum jelent meg, a felvételkori hemokultúrákból közben 3-as szerotípusú, ceftriaxonérzékeny Streptococcus pneumoniae tenyészett. A képet súlyosbította, hogy a beteg hasmenése a kórházban fokozódott, laborjában azonban jelentős felszívódási zavar nem mutatkozott, a széklettenyésztés és Clostridium difficile toxinkimutatás fertőző etiológiát nem igazolt. Kolonoszkópia során a vastagbélben kicsi, elszórt gyulladásos foltokat láttunk, ezért ex iuvantibus sulfasalazint indítottunk, emellett a beteg székelési habitusa normalizálódott. A 10. napon készült újabb RTG alapján felvetődött légsarló megjelenése a korábbi homály területén. Mellkasi CT a bal felső lebenyben $10 \times 15 \mathrm{~cm}$-es tályogot igazolt. Az ekkor levett hemokultúrák már sterilnek bizonyultak. Ceftriaxont összesen 12 napig adtunk, ezután p. o. $3 \times 1000 \mathrm{mg}$ amoxicillinre váltottunk 14 napig. A kontroll-RTG-ek lassú, de fokozatos regressziót írtak le. A beteg nem szteroid gyulladásgátló mellett teljesen láztalanodott, laboreltérései lassan regrediáltak, vérképét a továbbiakban tartotta. Összesen 34 napot töltött kórházban."

A fertőzés kialakulásának és súlyos lefolyásának rizikófaktorait az 1. táblázatban foglaltuk össze [26, 27, 28, 29, 30, 31, 32, 33]. Kiemelkednek az életkori szélsőségek, valamint az immunrendszer átmeneti vagy tartós ledáltságát eredményező szerzett és veleszületett állapotok. Magyarországon a felnőttek körében a dohányzás, alkoholizmus, cukorbetegség, valamint krónikus szív- és tüdőbetegség jelent veszélyállapotot. Az S. pneumoniaepneumonia lokális szövődménye a parapneumoniás effusio, a thoracalis empyema, a tüdőabscessus és a nekrotizáló pneumonia. A pleuralis effusio gyakori szövődmény, hátterében steril parapneumoniás transsudatum áll, amely a tüdőgyulladás oldódásával párhuzamosan felszívódik. Mellkasi empyema az összes pneumoniás eset 5-12\%-ában lép fel [34]. Viszonylag ritka szövődmény a tüdőabscessus és a nekrotizáló pneumonia: egy nemrég publikált retrospektív vizsgálat szerint az összes $S$. pneumoniae-pneumonia 6,6\%-ában láttak tüdőnecrosisnak megfelelő radiológiai jeleket [35]. A pneumonia következménye gépi lélegeztetést igénylő akut légzési elégtelenség kifejlődése is lehet. A szövődmények másik csoportjába az akut cardialis történések tartoznak. Egy tanulmány szerint leggyakrabban akut myocardialis infarctus, új keletű pitvarfibrilláció vagy kamrai tachycardia, valamint akut szívelégtelenség fordul elő a betegség kezdeti szakaszán. A betegek döntő többsége 70 évnél idősebb volt, anamnesztikus szívbetegségük nem volt [36].

\section{A diagnosztika, terápia és megelőzés sajátosságai}

\section{A prevenció fontossága}

„A 65 éves nőbeteg anamnézisében évek óta gondozott hypertonia, COPD, dohányzás, 2-es típusú cukorbetegség, valamint 2 rekurrens gennyes agyhártyagyulladás szerepel. A meningitises epizódokat Streptococcus pneumoniae törzsek okozták, de fertőzésre hajlamosító té- 
1. táblázat |S. pneumoniae-infekciók kialakulásának és súlyos lefolyásának ismert rizikófaktorai a veszélyeztetett csoportok szerinti bontásban

\begin{tabular}{|c|c|}
\hline Rizikócsoport & Állapot vagy alapbetegség \\
\hline Életkor & $<2$ vagy $\geq 65$ éves kor \\
\hline Rassz & Afrikaiak, eszkimók, indiánok \\
\hline \multirow[t]{11}{*}{ Immunkompetensek } & Megelőző influenzainfekció \\
\hline & Krónikus szívbetegség ${ }^{1}$ \\
\hline & Krónikus tüdőbetegség ${ }^{2}$ \\
\hline & $\begin{array}{l}\text { Krónikus májbetegség, } \\
\text { májcirrhosis }\end{array}$ \\
\hline & Diabetes mellitus \\
\hline & Alkoholizmus \\
\hline & Dohányzás \\
\hline & Terhesség \\
\hline & Hajléktalan állapot \\
\hline & Liquorcsorgással járó állapotok \\
\hline & Cochlearis implantátum \\
\hline \multirow[t]{13}{*}{ Immunszupprimáltak } & $\begin{array}{l}\text { Congenitalis vagy szerzett } \\
\text { immundeficientiák }^{3}\end{array}$ \\
\hline & Iatrogén immunszuppresszió ${ }^{4}$ \\
\hline & HIV-infekció \\
\hline & Krónikus vesebetegség \\
\hline & Nephrosisszindróma \\
\hline & Leukaemia \\
\hline & Lymphoma \\
\hline & Hodgkin-betegség \\
\hline & Myeloma multiplex \\
\hline & Malignoma \\
\hline & Szervtranszplantáltak \\
\hline & $\begin{array}{l}\text { Haematopoeticusőssejt- } \\
\text { transzplantáltak }\end{array}$ \\
\hline & SLE \\
\hline \multirow[t]{3}{*}{$\begin{array}{l}\text { Funkcionális vagy anatómiai } \\
\text { asplenia }\end{array}$} & $\begin{array}{l}\text { Congenitalis vagy akvirált } \\
\text { asplenia }\end{array}$ \\
\hline & Sarlósejtes anaemia \\
\hline & Egyéb haemoglobinopathiák \\
\hline
\end{tabular}

${ }^{1}$ Szívelégtelenség, cardiomyopathiák, de a hypertensio önmagában nem.

${ }^{2}$ COPD, emphysema, asthma bronchiale.

${ }^{3} \mathrm{~B}$ - vagy T-sejtes, fagocitafunkció-zavarok, komplementdeficientia, de a krónikus granulomatosus betegség önmagában nem.

${ }^{4}$ Alkilálószerek, antimetabolitok, szisztémás glükokortikoidok, irradiációs terápia.

nyezőt fül-orr-gégészeti, képalkotó és laborvizsgálatokkal nem sikerült feltárni. A beteget ezúttal eszméletlenül (GCS 6/E2VtM4), intubálva-lélegeztetve szállították a kórház intenzív osztályára. Heteroanamnézis szerint a beteg pár napja fülfájást említett. Belgyógyászati és neurológiai vizsgálatakor teljes dekontaktságon kívül más kórjelzőt nem találtunk, meningealis izgalom nem volt jelen. Fül-orr-gégészeti vizsgálat során jobb oldali genynyes otitis media igazolódott. Laborjából kiemelendő súlyos szepszisnek megfelelő leukocytosis $(38,3 \mathrm{G} / 1$, 97,7\% neutrophil), CRP (380 mg/l) és PCT (50 ng/ $\mathrm{ml}$ ), valamint máj- (>3000 IU/1 SGPT és SGOT, 125 umol/1 bilirubin) és vesefunkciós zavar $(35,2 \mathrm{mmol} / \mathrm{l}$ karbamid, 236 umol/1 kreatinin). A beteg mellkasi felvétele negatív lett, a sürgösséggel elvégzett koponya-CT-n kifejezett meningealis halmozás látszódott. Lumbalpunctio során makroszkóposan zavaros liquort nyertünk, amely gennyes agyhártyagyulladásnak megfelelő laboreltéréseket mutatott, a belőle készült keneten Gram-pozitív diplococcusokat láttak. Otogen meningitis diagnózisával iv. $2 \times 2$ g ceftriaxont indítottunk, a beteg szupportációként gépi ventilációt, keringéstámogatást, parenteralis ion-, folyadék- és kalóriapótlást igényelt. A liquorból később 8-as szerotípusú, ceftriaxonérzékeny Streptococcus pneumoniae nőtt, a hemokultúrák többszöri ismétlés mellett is negatív eredményúek lettek. A beteget összesen 12 napig kezelték intenzív osztályon, tudata lassan visszatért, betegsége maradványtünet nélkül gyógyult. Utókezelésre, mobilizálásra osztályra kihelyezték, ahol még 14 napot ápolták eseménymentesen. Ceftriaxont összesen 21 napig kapott.”

Az S. pneumoniae okozta tüdőgyulladás klasszikus tünetei: hirtelen kezdetú magas láz, hidegrázás, hemoptysissel járó produktív köhögés és légzésszinkrón oldalszegező (pleuralis) fájdalom. A betegség progressziójával szepszisre jellemző tünetek, cyanosissal járó tachydyspnoe, hypotensio, tachycardia, tudatzavar léphet fel. Idős betegekben a tünetek nem feltétlen markánsak: monoszimptómás láz vagy delírium hátterében állhat pneumonia légúti panasz nélkül. Fulmináns tünetek mindig IPD-re gyanúsak. Fizikális vizsgálat során az érintett mellkasfél légzőmozgásainak elmaradását, renyhe rekeszkitérést, tompulatot, gyengült vagy vezetett bronchialis légzés mellett crepitatiót, konszonáló szörtyzörejeket, erősödő pectoralfremitust-bronchophoniát találhatunk. A felnőtt betegek állapotának felmérésekor hasznos a CAP-ok etiológiától független mortalitásbecslésére használt PSI/PORT score meghatározása, amely súlyosság szerint I-V. rizikócsoportokba stratifikálja a betegeket [37]. S. pneumoniae pneumonia gyanúja esetén kötelező a függőleges testhelyzetben készített kétirányú mellkas-röntgenfelvétel, amelyen típusos esetben levegőbronchogramot és lobaris konszolidációnak megfelelő infiltrátumot, ritkább esetben levegőbronchogram nélküli apró gócokat, foltos homályokat láthatunk. Az IPD gyanújának kizárására hemokultúrák ismételt vétele (2-3 pár), meningealis érintettség esetén liquordiagnosztika (liquorsejtszám és -összetétel, liquorcukor/vércukor arány, liquorfehérje-koncentráció, pneumococcusantigén-gyorsteszt, Gram-festés és mikroszkópos kenetvizsgálat, liquortenyésztés) végzendő [38]. A köpet tenyésztése és a Gram szerint festett kenetének értékelése ellentmondásos. Mintavétel súlyos CAP-oknál 
ajánlott lehet, azonban az értékelésnél a tünetmentes hordozás lehetősége mellett figyelembe kell venni a mintavétel megfelelő voltát és a kórházi felvétel előtt bevezetett antibiotikus kezelés álnegativitást generáló hatását. Az infekcióra gyanús betegek 15-30\%-a felvételkor nem képes a mély légutakból adekvát köpetet spontán produkálni, emellett 25\%-uk valamilyen előzetes antibiotikumkezelésben is részesül $[3,39]$. Egy másik tanulmány szerint azonban a bacteraemiával járó pneumoniák 63\%-ában a köpetkenet igazolta az $S$. pneumoniae kóroki szerepét, amennyiben antibiotikum-szedés nem történt és a beteg képes volt spontán „mély” minta ürítésére [40]. A pneumococcusantigén-teszt membránalapú immunkromatográfiás próba, amely a tokpoliszacharida kimutatásán alapszik. A gyorstesztet vizelet- és/vagy liquorminta vizsgálatával IPD diagnosztikájára törzskönyvezték. A vizeletantigén gyors vizsgálata különösképpen a háziorvosi praxisban és a sürgősségi osztályokon volna kívánatos, azonban Magyarországon a teszt nem hozzáférhető. Újabban felmerült, hogy az inkubáció alatt növekedést mutató, de a kioltás során autolizáltnak minősített hemokultúrás palackokból történjen antigéngyorsteszt az S. pneumoniae jelenlétének (retrospektív) igazolására, azonban a fals pozitív minták magasabb aránya miatt további vizsgálatok szükségesek a rutinszerú alkalmazás bevezetése előtt [41]. Létezik polimeráz láncreakció (PCR) alapú pneumococcusteszt is, azonban a módszer ára és múszerigénye miatt Magyarországon nem terjedt el. A mikrobiológiai vizsgálatok együttes értékelése növelheti a diagnosztikus szenzitivitást és specificitást.

A CAP-ok empirikus antibiotikus terápiája során antipneumococcalis szereket is alkalmazunk [19]. A nemzetközi ajánlások alapján a dokumentáltan penicillinszenzitív pneumococcus okozta infekció béta-laktámmal kezelhető. A mérsékelt érzékenységet mutató törzsek által kiváltott fertőzések magasabb dózisú béta-laktám adásával kompenzálhatók. Az empirikusan megkezdett béta-laktám-monoterápia alacsony rizikóstátusú betegek körében jól alkalmazható a továbbiakban, náluk az 5-7 napos antimikrobás kezelés elegendő lehet. Korai kombinált antibiotikus kezelés (béta-laktám és makrolid vagy légúti kinolon) szóba jön krónikus betegségben szenvedő, súlyos lefolyású vagy intenzív osztályos ellátást igénylő, IPD-vel diagnosztizált betegek esetében. Bizonyított pneumococcusbacteraemia esetén (a fókusztól függetlenül) 10-14 napos antimikrobás kezelés ajánlott. Ha felvételkor a meningitisgyanú nem zárható ki egyértelmüen, emelt dózisú ceftriaxon és vancomycin együttes adását kell választanunk. A kombinációs terápiát nem feltétlen szükséges 4-5 napnál tovább fenntartani, a monoterápiára való átállás megkezdhető az érzékenységi vizsgálatok eredményének függvényében [42].

Az $S$. pneumoniae ellen többféle aktív immunizáció is létezik. Az 1983 óta alkalmazott 23-valens poliszacharid vakcina (PPV23: 1, 2, 3, 4, 5, 6B, 7F, 8, 9N, 9V, 10A, $11 \mathrm{~A}, 12 \mathrm{~F}, 14,15 \mathrm{~B}, 17 \mathrm{~F}, 18 \mathrm{C}, 19 \mathrm{~F}, 19 \mathrm{~A}, 20,22 \mathrm{~F}, 23 \mathrm{~F}$ és $33 \mathrm{~F}$ ) immunogenitásáról a vizsgálatok során kiderült, hogy immunmemória kialakulásával nem jár, nem befolyásolja a garathordozást és 2 év alatti gyermekekben nem immunogén. A PPV23-mal történő későbbi revakcináció során megfigyelték, hogy az előzőhöz képest alacsonyabb antitestválasz lépett fel (hiporeszponzivitás) [43]. Egy metaanalízis az immunkompetens, egészséges felnőtteknél az IPD megelőzésében 50-80\%-os hatékonyságúnak találta a PPV23 vakcinát, ugyanakkor magas rizikóstátusú betegeknél nem volt bizonyítható a védőhatás IPD vagy pneumonia ellen, és az oltás nem befolyásolta a halálozást [44]. A közelmúltban elérhetővé vált a 13 -valens konjugált vakcina (PCV13: 1, 3, 4, 5, $6 \mathrm{~A}, 6 \mathrm{~B}, 7 \mathrm{~F}, 9 \mathrm{~V}, 14,18 \mathrm{C}, 19 \mathrm{~A}, 19 \mathrm{~F}$ és $23 \mathrm{~F}$ ) is, amelynek beadása után immunmemória marad vissza, így az oltás jól boosterelhető. Alkalmazható 2 évesnél kisebb gyermekek esetén is, a vakcinában lévő szerotípusok pharyngealis hordozását pedig megszünteti [43]. Egy idén publikált randomizált-kontrollált prospektív vizsgálat (CAPITA) tanúsága szerint a 65 éves vagy idősebb felnőttekben a PCV13 igen hatékonynak bizonyult a vakcinatörzsek által okozott, bacteraemiával vagy a nélkül járó CAP és IPD előfordulásának kivédésében [45]. Az irodalom szerint bizonyos immunkárosodott betegek (például cardiovascularis betegségek, COPD, diabetes mellitus, dialízis, asplenia, HIV/AIDS) PCV13-mal történő oltása során az egészségesekével azonos immunválaszt kaptak [46]. A pneumococcus elleni vakcináció jelentőségét szemlélteti, hogy a nemzetközi (CDC) és magyar (OEK) ajánlások alapján a Magyar Infektológiai és Klinikai Mikrobiológiai Társaság (MIFKMT) 2014-ben egységes szakmai állásfoglalást fogadott el az oltás indikációjával és módjával kapcsolatban [26, 47, 48]. A szakanyag alapján vakcináció javasolt: 1. 50 év felett mindenkinek; 2. krónikus betegeknek, akik alapbetegségük miatt fogékonyak a súlyos infekcióra (tüdő-, szív-, vese-, máj- és cukorbetegek, immunszupprimáltak); 3. dohányosoknak; 4. belsőfül-mútéten átesetteknek és koponyasérülteknek; 5. léphiányosoknak. Akik korábban még nem részesültek oltásban, azoknál PCV13-mal kezdjük a vakcinációt, majd minimum 8 hét eltelte után lehet szélesíteni a védelmet PPV23-mal. Akik korábban, de 65 éves koruk felett részesültek immunizációban PPV23-mal, azoknál ajánlott a PCV13 beadása is minimum 1 évvel a PPV23 után. Aki 65 éves életkora előtt lett oltva PPV23mal, annak minimum 1 évvel a PPV23 után a PCV13 beadása is javallott, valamint minimum 8 hét eltelte után PPV23 emlékeztető oltás is javasolt, ha legalább 5 év telt el az előző PPV23 vakcina beadása óta. Örvendetes előrelépés, hogy a 2015. évi oltási naptárban életkorhoz kötött kötelező védőoltásként szerepel a pneumococcus elleni konjugált vakcina a csecsemők számára [48].

\section{Megbeszélés}

A bemutatott esetek kapcsán is igazolható, hogy a pneumococcusfertőzések súlyossága, kimenetele és szövődményei nem egy-egy rizikófaktor szigorúan vett meglé- 
tén vagy hiányán, hanem sokkal inkább a gazdaszervezet és a baktérium közötti bonyolult kölcsönhatáson múlik. A megbetegedés lefolyása összefügg a rizikófaktorokkal, a beteg védekezőképességével. A kórokozó oldaláról a virulenciafaktorok és a szerotípus determinálja az infekció klinikai lefolyását. Kiemelkedő jelentősége van a garatkolonizációnak is.

A pneumococcus okozta CAP típusos légúti panaszai inkább fiatalkorban kifejezettek. Ritkább esetekben az S. pneumoniae-infekció hosszabb prodromával, atípusos tünetekkel is kezdődhet. Egyik bemutatott betegünknél a bőrkiütés és a hasmenés is feltehetően a korai pneumococcusbacteraemia részjelensége volt. Ismert COPD-s betegeknél a köhögés és köpetürítés minőségi, mennyiségi változása, valamint vérköpés fellépte alarmírozhat tüdőgyulladásra. Fizikális vizsgálat során a mellkasi tompulat és a crepitatio perdöntő lehet, markáns eltérések hiányában a dyspnoés jelek az irányadóak. A bemutatott esetekben a mellkasi röntgenfelvételen az $S$. pneumoniaepneumoniában gyakorinak mondható lobaris pneumonia képét láttuk, párhuzamosan fellépő pleuralis effusióval.

A CAP diagnosztikája során nélkülözhetetlen lépés a pneumococcus etiológiai szerepét és az IPD fennállását egyértelmûsítő hemokultúra levétele. A primer fókusz (tüdő, középfül) valamennyi esetben szekunder véráramfertőzést is okozott. Sajnálatos módon Magyarországon a hemokultúrák időben történő és szabályos levételét ma még mindig elhanyagolják. A pneumonia diagnosztikájának része kell legyen a rizikófaktorok felmérése is. Hajlamosító tényezőkkel rendelkező betegek esetében az S. pneumoniae-fertőzések szövődményes lefolyásával még korai hospitalizáció és időben megkezdett adekvát antibiotikum-kezelés mellett is számolni kell. Egyik bemutatott esetünkben a tályogképződés ceftriaxon korai adása mellett lépett fel. Ennek ellenére a béta-laktámok klinikailag sikeresen alkalmazhatók a noninvazív és invazív pneumococcusfertőzésekben egyaránt.

Az eseteket a 2014/2015. évi, magas megbetegedési aránnyal járó influenzaszezonban gyưjtöttük, ekkor ugyanis rövid idő alatt több IPD-s beteg került hospitalizációra intézményünkben. A bemutatott páciensek mindegyike nagy rizikójú volt, azonban egyikőjük sem részesült pneumococcus elleni védőoltásban. Valamenynyiük betegségét vakcinatörzs okozta. Az immunizáció nagy eséllyel mind a négy beteg infekcióját elkerülhetővé tette volna. A vakcináció elmaradása különösen az eszméletlenül, harmadik recidív $S$. pneumoniae-fertőzésével hospitalizált beteg esetében vet fel súlyos aggályokat. Kívánatos volna az influenzaszezon előtt a betegek vakcinációs anamnézisét és rizikófaktorait felmérni, a szükséges oltás(oka)t pedig a legújabb felnőttkori ajánlások figyelembevételével beadni az invazív pneumococcusfetőzések, a súlyos szövődmények és fatális kimenetel előfordulásának csökkentése érdekében.
Anyagi támogatás: A közlemény megírása anyagi támogatásban nem részesült.

Szerzôi munkamegosztás: Sz. B. G.: Irodalomkutatás, az esetismertetések egységesítése, az összefoglaló és a kézirat megszövegezése. L. K. Sz.: A leletek beszerzése, a kézirat nyelvi lektorálása. K. B., G. A., D. B., Sz. J.: Esetismertetés. B. I.: Szakmai tanácsok, a kézirat szakmai lektorálása. P. Gy.: Szakmai vezetés, a kézirat szakmai lektorálása. A cikk végleges változatát valamennyi szerző elolvasta és jóváhagyta.

Érdekeltségek: A szerzőknek nincsenek érdekeltségeik.

\section{Köszönetnyilvánítás}

A szerzők köszönetet mondanak az Egyesített Szent István és Szent László Kórház-Rendelőintézet Központi Mikrobiológiai Laboratórium és Központi Radiológiai Osztály munkatársainak a leletekért, valamint $d r$. Tirczka Tamásnak (OEK Pneumococcus Referencia Laboratórium) a baktériumok tipizálásában nyújtott segítségért.

\section{Irodalom}

[1] World Health Organization: Pneumococcal disease. Last updated: 11 October 2011. doi: http://www.who.int/immunization/topics/pneumococcal_disease/en/

[2] Centers for Disease Control and Prevention: Epidemiology and prevention of vaccine-preventable diseases. 12th ed. Public Health Foundation, Washington, 2012.

[3] Marrie, T., Durant, H., Yates, L.: Community-acquired pneumonia requiring hospitalization: 5-year prospective study. Rev. Infect. Dis., 1989, 11(4), 586-599.

[4] Huang, S. S., Johnson, K. M., Ray, G. T., et al.: Healthcare utilization and cost of pneumococcal disease in the United States. Vaccine, 2011, 29(18), 3398-3412.

[5] Meszner, Z., Laszlo, S.: Prospective evaluation of the incidence of IPD (invasive pneumococcal disease), the serotypes and resistance of Streptococcus pneumoniae isolates in hospitalised Hungarian children $<5$ y. Two years observational study. Presented at the European Society for Paediatric Infectious Disease (ESPID), 2005, Valencia, Spain.

[6] Centers for Disease Control and Prevention: Active Bacterial Core Surveillance Report: Emerging Infections Program Network Streptococcus pneumoniae, 2012. 2013. doi: http://www.cdc. gov/abcs/reports-findings/survreports/spneu12.html

[7] National Center for Epidemiology: Current state and results of pneumococcus surveillance, Hungary, 2012 October. [Országos Epidemiológiai Központ. A pneumococcus surveillance jelenlegi helyzete és eredményei, Magyarország, 2012. október.] Epinfo, 2012, 19(45), 521-528. [Hungarian]

[8] Ivády, B., Liptai, Z., Ujhelyi, E., et al.: Pneumococcal meningitis in children - 9 1/2-year experience at Szent László Hospital, Budapest, Hungary. [Pneumococcus-meningitis gyermekkorban - kilenc és fél év tapasztalata a Szent László kórházban.] Ideggyogy. Sz., 2008, 61(11-12), 385-390. [Hungarian]

[9] Ludwig, E., Jorgensen, L., Gray, S., et al.: Clinical burden of multi-cause and pneumococcal pneumonia, meningitis, and septicemia in Hungary. Results of a retrospective study (2006-2011). [Pneumococcus, illetve bármely kórokú pneumonia, meningitis és septikaemia miatti hospitalizáció és halálozás Magyarországon - Egy retrospektív értékelés eredménye (2006-2011).] Orv. Hetil., 2014, 155(36), 1426-1436. [Hungarian] 
[10] Boada, A., Almeda, J., Grenzner, E., et al.: Prevalence of nasal carriage of Staphylococcus aureus and Streptococcus pneumoniae in primary care and factors associated with colonization. Enferm. Infecc. Microbiol. Clin., 2015, 33(7), 451-457.

[11] Yagupsky, P., Porat, N., Fraser, D., et al.: Acquisition, carriage, and transmission of pneumococci with decreased antibiotic susceptibility in young children attending a day care facility in southern Israel. J. Infect. Dis., 1998, 177(4), 1003-1012.

[12] Hussain, M., Melegaro, A., Pebody, R. G., et al.: A longitudinal household study of Streptococcus pneumoniae nasopharyngeal carriage in a UK setting. Epidemiol. Infect., 2005, 133(5), 891898.

[13] Song, J. H., Jung, S. I., Ko, K. S., et al.: High prevalence of antimicrobial resistance among clinical Streptococcus pneumoniae isolates in Asia (an ANSORP study). Antimicrob. Agents Chemother., 2004, 48(6), 2101-2107.

[14] Musher, D.: Resistance of Streptococcus pneumoniae to betalactam antibiotics 2014. doi: http://www.uptodate.com/contents/resistance-of-streptococcus-pneumoniae-to-beta-lactamantibiotics

[15] Patel, S. N., McGeer, A., Melano, R., et al.: Susceptibility of Streptococcus pneumoniae to fluoroquinolones in Canada. Antimicrob. Agents Chemother., 2011, 55(8), 3703-3708.

[16] Jones, R. N., Jacobs, M. R., Sader, H. S.: Evolving trends in Streptococcus pneumoniae resistance: Implications for therapy of community-acquired bacterial pneumonia. Int. J. Antimicrob. Agents, 2010, 36(3), 197-204.

[17] Zhanel, G. G., Palatnick, L., Nichol, K. A., et al.: Antimicrobial resistance in respiratory tract Streptococcus pneumoniae isolates: Results of the Canadian Respiratory Organism Susceptibility Study, 1997 to 2002. Antimicrob. Agents Chemother., 2003, 47(6), 1867-1874.

[18] Doern, G. V., Richter, S. S., Miller, A., et al.: Antimicrobial resistance among Streptococcus pneumoniae in the United States: have we begun to turn the corner on resistance to certain antimicrobial classes? Clin. Infect. Dis., 2005, 41(2), 139-148.

[19] Mandell, L. A., Wunderink, R. G., Anzueto, A., et al.: Infectious Diseases Society of America/American Thoracic Society consensus guidelines on the management of community-acquired pneumonia in adults. Clin. Infect. Dis., 2007, 44(Suppl. 2), S27-72.

[20] National Center for Epidemiology: Antibiotics sensitivity of Streptococcus isolates registered in monitoring system in 2013. Antibiotics resistance results of the national microbiologic surveillance programme. [Országos Epidemiológiai Központ: A monitor rendszerben 2013. évben jelentett Streptococcus pneumoniae izolátumok antibiotikum érzékenysége. A hazai mikrobiológiai surveillance antibiotikum rezisztencia eredményei, 2013.] [Hungarian]

[21] Blumental, S., Granger-Farbos, A., Moïsi, J. C., et al.: Virulence factors of Streptococcus pneumoniae. Comparison between African and French invasive isolates and implication for future vaccines. PLoS ONE, 2015, 10(7), e0133885.

[22] Brueggemann, A. B., Peto, T. E., Crook, D. W., et al.: Temporal and geographic stability of the serogroup-specific invasive disease potential of Streptococcus pneumoniae in children. J. Infect. Dis., 2004, 190(7), 1203-1211.

[23] Østergaard, C., Brandt, C., Konradsen, H. B., et al.: Differences in survival, brain damage, and cerebrospinal fluid cytokine kinetics due to meningitis caused by 3 different Streptococcus pneumoniae serotypes: evaluation in humans and in 2 experimental models. J. Infect. Dis., 2004, 190(7), 1212-1220.

[24] Hausdorff, W. P., Feikin, D. R., Klugman, K. P.: Epidemiological differences among pneumococcal serotypes. Lancet Infect. Dis., $2005,5(2), 83-93$.

[25] Garnacho-Montero, J., García-Cabrera, E., Jiménez-Álvarez, R., et al.: Genetic variants of the MBL2 gene are associated with mortality in pneumococcal sepsis. Diagn. Microbiol. Infect. Dis., 2012, 73(1), 39-44.

[26] Use of 13-valent pneumococcal conjugate vaccine and 23-valent pneumococcal polysaccharide vaccine for adults with immunocompromising conditions: recommendations of the Advisory Committee on Immunization Practices (ACIP). MMWR Morb. Mortal. Wkly Rep., 2012, 61(40), 816-819.

[27] Pneumococcal vaccination for cochlear implant candidates and recipients: updated recommendations of the Advisory Committee on Immunization Practices. MMWR Morb. Mortal. Wkly Rep., 2003, 52(31), 739-740.

[28] Gentile, J. H., Sparo, M. D., Mercapide, M. E., et al.: Adult bacteremic pneumococcal pneumonia acquired in the community. A prospective study on 101 patients. Medicina (Buenos Aires), 2003, 63(1), 9-14.

[29] Laupland, K. B., Gregson, D. B., Zygun, D. A., et al.: Severe bloodstream infections: a population-based assessment. Crit. Care Med., 2004, 32(4), 992-997.

[30] Talbot, T. R., Hartert, T., V., Mitchel, E., et al.: Asthma as a risk factor for invasive Pneumococcal disease. N. Engl. J. Med., 2005, 352(20), 2082-2090.

[31] Chi, R. C., Jackson, L. A., Neuzil, K. M.: Characteristics and outcomes of older adults with community-acquired pneumococcal bacteremia. J. Am. Geriatr. Soc., 2006, 54(1), 115-120.

[32] Cruickshank, H. C., Jefferies, J. M., Clarke, S. C.: Lifestyle risk factors for invasive pneumococcal disease: a systematic review. BMJ Open, 2014, 4, e005224.

[33] Nuorti, J. P., Butler, J. C., Farley, M. M., et al.: Cigarette smoking and invasive pneumococcal disease. N. Engl. J. Med., 2000, 342(10), 681-689.

[34] Burgos, J., Lujan, M., Falcó, V., et al.: The spectrum of pneumococcal empyema in adults in the early 21 st century. Clin. Infect. Dis., 2011, 53(3), 254-261.

[35] Pande, A., Nasir, S., Rueda, A. M., et al.: The incidence of necrotizing changes in adults with pneumococcal pneumonia. Clin. Infect. Dis., 2012, 54(1), 10-16.

[36] Musher, D. M., Rueda, A. M., Kaka, A. S., et al.: The association between pneumococcal pneumonia and acute cardiac events. Clin. Infect. Dis., 2007, 45(2), 158-165.

[37] Fine, M. J., Auble, T. E., Yealy, D. M., et al.: A prediction rule to identify low-risk patients with community-acquired pneumonia. N. Engl. J. Med., 1997, 336(4), 243-250.

[38] Towns, M. L., Jarvis, W. R., Hsueh, P. R.: Guidelines on blood cultures. J. Microbiol. Immunol. Infect., 2010, 43(4), 347-349.

[39] Musher, D. M., Montoya, R., Wanabita, A.: Diagnostic value of microscopic examination of Gram-stained sputum and sputum cultures in patients with bacteremic pneumococcal pneumonia. Clin. Infect. Dis., 2004, 39(2), 165-169.

[40] García-Vázquez, E., Marcos, M. A., Mensa, J., et al.: Assessment of the usefulness of sputum culture for diagnosis of communityacquired pneumonia using the PORT predictive scoring system. Arch. Intern. Med., 2004, 164(16), 1807-1811.

[41] Baggett, H. C., Rhodes, J., Dejsirilert, S., et al.: Pneumococcal antigen testing of blood culture broth to enhance the detection of Streptococcus pneumoniae bacteremia. Eur. J. Clin. Microbiol. Infect. Dis., 2012, 31(5), 753-756.

[42] Marrie, J., Tuomanen, E.: Pneumococcal pneumonia in adults 2014. doi: http://www.uptodate.com/contents/pneumococcal-pneumonia-in-adults

[43] Pollard, A. J., Perrett, K. P., Beverley, P. C.: Maintaining protection against invasive bacteria with protein-polysaccharide conjugate vaccines. Nat. Rev. Immunol., 2009, 9(3), 213-220.

[44] Moberley, S., Holden, J., Tatham, D. P., et al.: Vaccines for preventing pneumococcal infection in adults. Cochrane Database Syst. Rev., 2008, 1, CD000422. 
[45] Bonten, M. J., Huijts, M., Bolkenbaas, S. M., et al.: Polysaccharide conjugate vaccine against pneumococcal pneumonia in adults. N. Engl. J. Med., 2015, 372(12), 1114-1125.

[46] Cordonnier, C., Averbuch, D., Maury, S., et al.: Pneumococcal immunization in immuncompromised hosts: where do we stand? Expert Rev. Vaccines, 2014, 13(1), 59-74.

[47] Ludwig, E., Mészner, Z.: Prevention of Streptococcus pneumoniae (pneumococcus) infections in adults. Recommendation of the Vaccinology Section of Hungarian Society of Infections Disease and Clinical Microbiology (October 2014). [A Streptococcus pneumoniae (pneumococcus) infekciók megelőzése felnőttekben. A Magyar Infektológiai és Klinikai Mikrobiológiai Társaság Vakcinológiai Szekciójának állásfoglalása (2014. október).] Orv. Hetil., 2014, 155(50), 1996-2004. [Hungarian]
[48] National Center for Epidemiology: Methodological letter of the National Center for Epidemiology on vaccination in 2015. [Országos Epidemiológiai Központ: Az Országos Epidemiológiai Központ módszertani levele a 2015. évi védőoltásokról.] Epinfo, 2015, 22(1. különszám), 1-61. [Hungarian]

(Szabó Bálint Gergely dr., Budapest, Albert Flórián út 5-7., 11. épület, 1. emelet, 1097 e-mail: szabo.balint.gergely@freemail.hu)

A cikk megjelenését a Pfizer Kft. támogatta.

\section{Tisztelt Szerzőink, Olvasóink!}

Az Orvosi Hetilapban megjelenő/megjelent közlemények elérhetőségére több lehetőség kínálkozik.

Rendelhető különlenyomat, melynek áráról bővebben a www.akkrt.hu honlapon (Folyóirat Szerzőknek, Különlenyomat menüpont alatt) vagy Szerkesztőségünkben tájékozódhatnak.

A közlemények megvásárolhatók pdf-formátumban is, illetve igényelhető Optional Open Article (www.oopenart.com).

Adott dij ellenében az online közlemények bárki számára hozzáférhetők honlapunkon (a közlemények külön linket kapnak, így más oldalról is linkelhetővé válnak).

Bővebb információ a hirdetes@akkrt.hu címen vagy különlenyomat rendelése esetén a Szerkesztőségtől kérhető. 